\title{
Hematologic reference intervals of Danish sows at mid-gestation
}

\author{
Sheeva Bhattarai ${ }^{1 *}\left(\mathbb{D}\right.$, Tore Framstad ${ }^{2}$ and Jens Peter Nielsen ${ }^{1}$
}

\begin{abstract}
Hematologic reference intervals are useful tools for interpretation of laboratory results in swine practice and research. Until now, there were no hematologic reference intervals established for gestating Danish sows and those established in other countries are either out-dated, produced using very few sows or incomplete with few variables. In the past few decades there have been significant increases in litter size due to breeding, as well as the development of new analytical procedures for hematology and statistical procedures for calculating reference intervals. Therefore, hematologic reference intervals representing current pig production and technology are greatly needed. The main objective of this study was to provide updated and complete hematologic reference intervals for Danish sows at mid-gestation. Blood samples were collected at mid-gestation from 248 sows belonging to five commercial herds in Denmark and the samples were analysed for several hematologic variables using the Advia 2120i Hematology System. The reference intervals were calculated according to the guidelines of American Society for Veterinary Clinical Pathology. The reference interval for hemoglobin concentration was 103.1-145.0 g/L. For red blood cells, hematocrit and mean corpuscular volume, the $95 \%$ reference intervals were $4.98-7.50 \times 10^{12} / \mathrm{L}, 0.32-0.47 \mathrm{~L} / \mathrm{L}, 57.0-69.3 \mathrm{fL}$, respectively. The reference intervals established in this study are different from those previously reported in the literature. These reference intervals add to the current knowledge and will be useful in the prevention, diagnosis and treatment of several disease conditions in gestating sow populations.
\end{abstract}

Keywords: Anemia, Hemoglobin, Iron, Pig, Pregnancy

\section{Findings}

Hematologic variables are important tools for herd veterinarians and researchers for diagnosing disease or interpretation of laboratory results. Until now very few hematologic variables have been used in swine practice because of the limited availability of reference intervals.

There are very few studies [1-3] that report hematologic reference intervals of gestating sows. There are no studies reporting reticulocyte variables in sows and we have recently shown that hematologic variables other than hemoglobin, namely reticulocyte variables indicate early stage iron deficiency in piglets [4]. There have been tremendous changes in genetics and performance of sows in particular relation to litter size, analytical

\footnotetext{
*Correspondence: sheeva@sund.ku.dk

${ }^{1}$ Department of Veterinary and Animal Sciences, Faculty of Health and Medical Sciences, University of Copenhagen, Grønnegårdsvej 2, 1870 Frederiksberg C, Denmark

Full list of author information is available at the end of the article
}

procedures for hematology and statistical procedures for calculating reference intervals. Therefore, there is a need for more recent reference intervals of complete hematologic variables including reticulocyte variables derived from current production and statistical procedures. Reference intervals produced for sows may vary within and between regions due to differences in breeding, feeding and other management procedures. Moreover, the reference intervals calculated for non-gestating sows may not be used for gestating sows [1], as several changes occur in the blood profile of sows during gestation. During mid-gestation, the hematological profile of sows might begin to change in order to supply the demand of rapidly growing fetuses. Therefore this study aimed at providing hematologic reference intervals for Danish sows at mid-gestation.

Five commercial sow herds with a minimum herd size of 1000 sows were selected for the study based on convenience in cooperation with a specialized veterinary

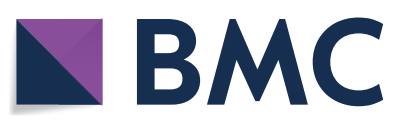

(c) The Author(s) 2019. This article is distributed under the terms of the Creative Commons Attribution 4.0 International License (http://creativecommons.org/licenses/by/4.0/), which permits unrestricted use, distribution, and reproduction in any medium, provided you give appropriate credit to the original author(s) and the source, provide a link to the Creative Commons license, and indicate if changes were made. The Creative Commons Public Domain Dedication waiver (http://creativecommons.org/ publicdomain/zero/1.0/) applies to the data made available in this article, unless otherwise stated. 
pig practice. In all herds, the sows were group-housed and were free from clinical disease based on observation. None of the farms used additional iron supplementation other than the iron present in feed. The standard recommendation of iron for pregnant sows is $80 \mathrm{mg} /$ $\mathrm{kg}$ [5]. From each herd, sows (Landrace $\times$ Yorkshire) at mid-gestation (56-70 days of gestation) were randomly selected. Fifty sows were sampled from each of the three herds while 47 and 51 sows were sampled from the other two herds, respectively. Blood was withdrawn into $10 \mathrm{~mL}$ EDTA tubes from the jugular vein of the snare-restrained sows and analysed within $24 \mathrm{~h}$.

The blood samples were analyzed for hematologic variables; hemoglobin concentration $(\mathrm{Hb})$, erythrocyte count (RBC), white blood cell count WBC (both peroxidase method and basophil method), neutrophils (absolute count and percentage), lymphocytes (absolute count and percentage), large unstained cells (LUC) (absolute count and percentage), monocytes (absolute count and percentage), eosinophils (absolute count and percentage), basophils (absolute count and percentage), red blood cell distribution width (RDW), hemoglobin distribution width (HDW), hematocrit (HCT), mean cell volume $(\mathrm{MCV})$, mean corpuscular hemoglobin $(\mathrm{MCH})$, mean cell hemoglobin concentration (MCHC), and corpuscular hemoglobin concentration mean (CHCM). Reticulocyte indices were also analyzed which included reticulocyte count (absolute and relative), reticulocyte hemoglobin content (Chr), reticulocyte corpuscular hemoglobin concentration mean (CHCMr), mean reticulocyte cellular volume $(\mathrm{MCVr})$, reticulocyte red cell distribution width (RDWr), and reticulocyte hemoglobin distribution width (HDWr).

Hemoglobin, MCHC, CHCM, HDW, $\mathrm{CHCMr}$ and HDWr values were converted from $\mathrm{mmol} / \mathrm{L}$ to $\mathrm{g} / \mathrm{L}$ by multiplying by a factor 16.11 for ease of comparison with other studies. Hematology testing was done using the Advia 2120i Hematology System (Siemens Healthcare Diagnostics Inc. Tarrytown, NY 10591, USA) at the Veterinary Diagnostic Laboratory, Department of Veterinary Clinical Sciences, University of Copenhagen.

$\mathrm{As} \mathrm{Hb}$ is the widely available hematologic variable for anemia diagnosis, sow with $\mathrm{Hb}$ value less than $100 \mathrm{~g} / \mathrm{L}$ was removed from the analysis considering the sow as anemic [6] as done previously [7]. In total, nine sows were excluded due to this leaving a total of 239 sows. According to the American Society for Veterinary Clinical Pathology (ASVCP) guidelines, mean, median, first quartile (Q1), median $(\mathrm{Q} 2)$ and third quartile $(\mathrm{Q} 3)$ were calculated using PROC MEANS procedure in SAS 9.4 (SAS institute Inc, Cary, NC, USA). The difference between Q3 and Q1 was calculated as an interquartile range (IQR). Each of the variables was checked for the presence of extreme outliers and those outliers were removed from the analysis. Extreme outliers were defined as the values that were $<\mathrm{Q} 1-3 \mathrm{IQR}$ or $>$ Q3 + 3IQR [8]. Whenever any extreme outlier was detected, the sow was excluded from further analysis. Subsequently, 16 sows were excluded due to the presence of outliers in one or more of the hematologic variables: HDW $(\mathrm{n}=3)$, absolute reticulocyte count $(\mathrm{n}=5)$, reticulocyte percentage $(\mathrm{n}=5), \operatorname{MCVr}(\mathrm{n}=3), \mathrm{RDWr}$ $(\mathrm{n}=3)$, CHCMr $(\mathrm{n}=3)$, HDWr $(\mathrm{n}=3), \operatorname{Chr}(\mathrm{n}=3)$, absolute neutrophil count $(\mathrm{n}=2)$, absolute and percentage eosinophil count $(n=3)$ and absolute LUC count $(n=1)$. This resulted in a final data set consisting of 223 sows. The $95 \%$ percentile reference intervals (2.5th and 97.5th percentile) method was used to determine the reference intervals because of sample size $>120$ as recommended by ASVCP [9]. The reference intervals with 90\% confidence limits were calculated with Reference Value Advisor (V.2.1) freeware, a set of macroinstructions for Microsoft Excel [10].

The reference intervals of erythrocyte and leucocyte variables including mean, median and range are presented in Tables 1 and 2, respectively.

The present study reported hematologic reference intervals for sows at mid-gestation. There are many factors that affect reference intervals. These factors include selection criteria of herds and animals, breed, age, stage of reproductive cycle, management conditions, season [1], blood-sampling strategies, duration between sampling and analysis, method of blood analysis, and method of data analysis. In this study, data from five herds were combined for the calculation of reference intervals in order to account for herd effect variations in Denmark. None of the farms used iron supplementation for the sows which could otherwise affect some blood variables. All the samplings were done during the winter to avoid seasonal variation if any and at the same gestational stage.

A review [11] has highlighted the importance of distinguishing physiological regulation by the body during pregnancy and pathological deviations from the normal while interpreting blood variables. The discussion on time-dependent reference intervals within veterinary medicine is on-going and our study contributes to the issue. Pregnancy in sows is a special physiological condition in which adjustment in hemopoiesis takes place for the growth and development of the fetus. Several changes in blood variables occur as the pregnancy progresses. In humans, the blood volume increases during pregnancy with decreases in $\mathrm{Hb}$ concentration [12] and hematocrit, increased reticulocyte numbers and increased MCV all depending on iron availability [13]. A similar change may occur in sows which explains the need of reference intervals for gestating sows. 
Table 1 Erythrocyte variables' reference intervals of Danish sows at mid-gestation

\begin{tabular}{|c|c|c|c|c|c|c|c|}
\hline \multirow[t]{2}{*}{ Variable } & \multirow[t]{2}{*}{ Unit } & \multirow[t]{2}{*}{$\mathbf{N}$} & \multirow[t]{2}{*}{ Mean } & \multirow[t]{2}{*}{ Median } & \multirow[t]{2}{*}{ Range (min-max) } & \multicolumn{2}{|c|}{ Reference limits with $90 \%$ confidence limits (CL) } \\
\hline & & & & & & Lower $(90 \% \mathrm{CL})$ & Upper $(90 \% \mathrm{CL})$ \\
\hline \multirow[t]{2}{*}{ Hemoglobin } & $\mathrm{Mmol} / \mathrm{L}$ & 223 & 7.5 & 7.4 & $6.3-10.5$ & $6.4(6.3-6.4)$ & $9.0(8.6-9.8)$ \\
\hline & $g / L$ & 223 & 120.3 & 119.2 & $101.5-169.1$ & $103.1(101.5-103.1)$ & $145.0(138.5-157.8)$ \\
\hline $\mathrm{RBC}$ & $10^{12} / \mathrm{L}$ & 223 & 6.14 & 6.07 & $4.86-8.99$ & $4.98(4.88-5.12)$ & $7.50(7.21-8.71)$ \\
\hline Hematocrit & $\mathrm{L} / \mathrm{L}$ & 223 & 0.39 & 0.38 & $0.32-0.55$ & $0.32(0.32-0.33)$ & $0.47(0.45-0.52)$ \\
\hline MCV & $\mathrm{fL}$ & 223 & 63.4 & 63.5 & $55.6-70.2$ & $57.0(56.3-57.9)$ & $69.3(68.3-70.0)$ \\
\hline $\mathrm{MCH}$ & fmol & 223 & 1.22 & 1.23 & $1.08-1.36$ & $1.09(1.09-1.10)$ & $1.34(1.34-1.36)$ \\
\hline \multirow[t]{2}{*}{$\mathrm{MCHC}$} & $\mathrm{Mmol} / \mathrm{L}$ & 223 & 19.27 & 19.28 & $18.21-21.02$ & $18.37(18.24-18.54)$ & $20.31(19.98-20.64)$ \\
\hline & $g / L$ & 223 & 310.43 & 310.60 & $293.36-338.63$ & $295.94(293.84-298.67)$ & $327.19(321.87-332.51)$ \\
\hline \multirow[t]{2}{*}{$\mathrm{CHCM}$} & $\mathrm{Mmol} / \mathrm{L}$ & 223 & 19.48 & 19.51 & $18.19-20.61$ & $18.64(18.42-18.76)$ & $20.35(20.10-20.55)$ \\
\hline & $g / L$ & 223 & 313.82 & 314.30 & 293.04-332.02 & $300.29(296.74-302.22)$ & $327.83(323.81-331.06)$ \\
\hline RDW & $\%$ & 223 & 15.7 & 15.7 & $13.7-18.5$ & $14.4(14.2-14.5)$ & $17.2(17.1-18.4)$ \\
\hline \multirow[t]{2}{*}{ HDW } & $\mathrm{Mmol} / \mathrm{L}$ & 223 & 1.00 & 0.99 & $0.86-1.28$ & $0.89(0.86-0.91)$ & $1.15(1.13-1.25)$ \\
\hline & $g / L$ & 223 & 16.11 & 15.94 & $13.85-20.62$ & $14.33(13.85-14.66)$ & $18.52(18.20-20.13)$ \\
\hline $\mathrm{CHr}$ & fmol & 223 & 1.32 & 1.32 & $1.13-1.51$ & $1.19(1.17-1.21)$ & $1.46(1.44-1.49)$ \\
\hline Retic \% & $\%$ & 223 & 0.5 & 0.4 & $0.1-1.4$ & $0.2(0.1-0.2)$ & $1.0(1.0-1.3)$ \\
\hline Retic & $10^{9} / \mathrm{L}$ & 223 & 29.8 & 25.8 & $6.4-93.0$ & $9.8(7.6-11.3)$ & $73.6(63.4-82.6)$ \\
\hline $\mathrm{MCVr}$ & $\mathrm{fL}$ & 223 & 78.7 & 78.7 & $67.1-91.2$ & $69.2(67.5-70.8)$ & $88.1(86.1-89.8)$ \\
\hline RDWr & $\%$ & 223 & 20.1 & 19.8 & $13.8-31.1$ & $14.7(13.9-14.9)$ & $29.0(27.2-30.5)$ \\
\hline \multirow[t]{2}{*}{$\mathrm{CHCMr}$} & $\mathrm{Mmol} / \mathrm{L}$ & 223 & 17.04 & 17.01 & $15.85-18.72$ & $16.13(15.91-16.19)$ & $18.29(18.06-18.66)$ \\
\hline & $g / L$ & 223 & 274.51 & 274.03 & 255.34-301.57 & $259.58(256.31-260.82)$ & 294.65 (290.94-300.61) \\
\hline \multirow[t]{2}{*}{ HDWr } & $\mathrm{Mmol} / \mathrm{L}$ & 223 & 2.33 & 2.29 & $1.38-3.91$ & $1.58(1.49-1.67)$ & $3.32(3.10-3.43)$ \\
\hline & $g / L$ & & 37.53 & 36.89 & $22.23-62.99$ & $25.77(24.00-26.90)$ & $53.48(49.94-55.25)$ \\
\hline
\end{tabular}

The number of digits after decimal point is presented as received from analyzer to ensure that precision level of the test is correctly presented. HCT values were obtained in three digits after decimal points which are rounded to two digits

$R B C$ red blood cell count, $M C V$ mean corpuscular volume, $M C H C$ mean cell hemoglobin concentration calculated based on $\mathrm{Hb}, \mathrm{MCV}$ and RBC, $C H C M$ mean cell hemoglobin concentration directly measured as cell-by-cell analysis, $M C H$ mean corpuscular hemoglobin, $M P V$ mean platelet volume, $R D W$ red blood cell distribution width, $\mathrm{HDW}$ hemoglobin distribution width, $\mathrm{MCV}$ r reticulocyte cellular volume, $\mathrm{CHCMr}$ mean reticulocyte corpuscular hemoglobin concentration, $\mathrm{Chr}$ reticulocyte hemoglobin content, $R D W r$ reticulocyte red cell distribution width, $H D W r$ reticulocyte hemoglobin distribution width, Min minimum, Max maximum

The reported lower reference limits of this study are different from the reference values reported in Canada [3]. In our study sows were excluded according to defined criteria for anemia. The upper reference value of $\mathrm{Hb}$ is extremely high $(170 \mathrm{~g} / \mathrm{L})$ in the Canadian study compared to the current study. Similarly, upper reference limits of RBC, MCHC, WBC, neutrophil \%, lymphocyte \%, lymphocyte absolute, monocyte \%, monocyte absolute, basophil \% and basophil absolute are higher in that study [3]. Upper reference limits of MCV, absolute neutrophil count, absolute eosinophil count and eosinophil \% are a bit high in our study while HCT values are similar in both studies. From 2013, all sows in Denmark are kept in groups by legal requirement starting from 4 weeks after service to 1 week before the expected date of farrowing. This might be a risk factor for parasitic infestation resulting in higher eosinophil numbers than found in other studies [1, 3]; this needs further investigation. However, a previous study [14] found a very low prevalence of parasitic infection in Denmark.
Better hematologic status in the sows reported by Friendship [3] is not surprising because the productivity of sows has dramatically changed over the last decades. The litter size in Denmark has increased continuously throughout the last 20 years from 12 to more than 18 piglets per litter [15]. The amount of iron required for fetal growth is therefore much higher now than in the past which requires sufficient iron stores in sows.

We recognize some limitations which should be considered while interpreting the reference intervals of this study. The study was done in apparently healthy sows, but sub-clinical infections and diseases were not considered. Furthermore, platelet variables could not be reported because of platelet aggregation as reflected by pseudothrombocytopenia. However, microscopic examination for detection of platelet aggregation was not done. It has been reported in human studies that platelet aggregation occurs with the use of anticoagulant EDTA [16, 17], which was used in the current study. 
Table 2 Leukocyte variables' reference intervals of Danish sows at mid-gestation

\begin{tabular}{|c|c|c|c|c|c|c|c|}
\hline \multirow[t]{2}{*}{ Variable } & \multirow[t]{2}{*}{ Unit } & \multirow[t]{2}{*}{$\mathbf{N}$} & \multirow[t]{2}{*}{ Mean } & \multirow[t]{2}{*}{ Median } & \multirow[t]{2}{*}{ Range (min-max) } & \multicolumn{2}{|c|}{$\begin{array}{l}\text { Reference limits with } 90 \% \text { confidence } \\
\text { limits (CL) }\end{array}$} \\
\hline & & & & & & Lower $(90 \% \mathrm{CL})$ & Upper $(90 \% \mathrm{CL})$ \\
\hline WBCP & $10^{9} / \mathrm{L}$ & 223 & 15.79 & 15.57 & $8.67-23.64$ & $10.12(9.67-10.82)$ & $22.24(21.49-22.88)$ \\
\hline WBCB & $10^{9} / \mathrm{L}$ & 223 & 15.09 & 14.09 & $8.01-22.89$ & $9.81(9.12-10.81)$ & $21.35(20.73-22.46)$ \\
\hline Neutrophils & $10^{9} / \mathrm{L}$ & 223 & 5.97 & 5.58 & $2.06-11.95$ & $3.04(2.23-3.34)$ & $10.94(9.73-11.64)$ \\
\hline Neutrophils & $\%$ & 223 & 38.4 & 38.0 & $22.6-57.8$ & $26.4(24.4-27.9)$ & $55.1(52.8-57.5)$ \\
\hline Eosinophils & $10^{9} / \mathrm{L}$ & 223 & 1.16 & 1.05 & $0.07-3.75$ & $0.19(0.11-0.38)$ & $2.81(2.50-3.18)$ \\
\hline Eosinophils & $\%$ & 223 & 7.4 & 6.9 & $0.5-19.0$ & $1.5(0.9-2.9)$ & $16.1(13.6-17.7)$ \\
\hline Basophils & $10^{9} / \mathrm{L}$ & 223 & 0.13 & 0.12 & $0.04-0.32$ & $0.05(0.05-0.06)$ & $0.24(0.22-0.28)$ \\
\hline Basophils & $\%$ & 223 & 0.8 & 0.8 & $0.4-1.7$ & $0.5(0.4-0.5)$ & $1.4(1.2-1.6)$ \\
\hline Monocytes & $10^{9} / \mathrm{L}$ & 223 & 0.64 & 0.60 & $0.14-1.26$ & $0.32(0.24-0.38)$ & $1.15(1.02-1.25)$ \\
\hline Monocytes & $\%$ & 223 & 4.2 & 4.0 & $1.4-7.4$ & $2.7(2.2-2.8)$ & $6.4(6.1-7.3)$ \\
\hline Lymphocytes & $10^{9} / \mathrm{L}$ & 223 & 7.28 & 7.18 & $3.50-12.52$ & $4.56(3.73-4.86)$ & $11.25(9.91-11.98)$ \\
\hline Lymphocytes & $\%$ & 223 & 47.8 & 48.2 & $30.4-68.2$ & $33.9(31.9-34.6)$ & $59.9(58.6-64.0)$ \\
\hline LUC & $10^{9} / \mathrm{L}$ & 223 & 0.22 & 0.22 & $0.02-0.68$ & $0.04(0.02-0.05)$ & $0.48(0.44-0.61)$ \\
\hline LUC & $\%$ & 223 & 1.4 & 1.4 & $0.1-3.5$ & $0.3(0.2-0.4)$ & $2.8(2.6-3.5)$ \\
\hline
\end{tabular}

The number of digits after decimal point is presented as received from the analyser

WBCP white blood cell determined by peroxidase method, WBCB white blood cell determined by basophile method, $L U C$ large unstained cells, Min minimum, Max maximum

In conclusion, this study generated up-to-date hematologic reference intervals for gestating sows that represent pig production with highly prolific sows. These reference intervals will be useful for herd veterinarians and researchers to diagnose a disease condition or better understand changes that occur in sows during the gestational period.

\begin{abstract}
Abbreviations
ASVCP: American Society for Veterinary Clinical Pathology; CHCM: corpuscular hemoglobin concentration mean; CHCMr: reticulocyte corpuscular hemoglobin concentration mean; Chr: reticulocyte hemoglobin content; $\mathrm{CL}$ : confidence limits; EDTA: ethylenediamine tetraacetic acid; $\mathrm{Hb}$ : hemoglobin; HCT: hematocrit; HDW: hemoglobin distribution width; HDWr: reticulocyte hemoglobin distribution width; IQR: interquartile range; LUC: large unstained cells; MCH: mean corpuscular hemoglobin; MCHC: mean cell hemoglobin concentration; MCV: mean cell volume; MCVr: mean reticulocyte cellular colume; Q1: first quartile; Q2: median (second quartile); Q3: third quartile; RBC: red blood cells (erythrocyte count); RDW: red blood cell distribution width; RDWr: reticulocyte red cell distribution width; WBC: white blood cell.
\end{abstract}

\section{Authors' contributions}

JPN and TF contributed to the design of the study. SB carried out the study and drafted the manuscript. All authors participated in the subsequent discussions and revisions of the entire text. All authors read and approved the final manuscript.

\section{Author details}

${ }^{1}$ Department of Veterinary and Animal Sciences, Faculty of Health and Medical Sciences, University of Copenhagen, Grønnegårdsvej 2, 1870 Frederiksberg C, Denmark. ${ }^{2}$ Department of Production Animal Clinical Sciences, Faculty of Veterinary Medicine, Norwegian University of Life Sciences, Campus Adamstuen, 0033 Oslo, Norway.

\section{Acknowledgements}

The authors wish to thank Pharmacosmos A/S, Denmark for funding the hematologic testing and transport. Danish veterinary pig practice $\varnothing$-vet is acknowledged for their help during herd selection process and blood sampling. Camilla Bygg and students at the Department of Veterinary and Animal Sciences are thanked for assisting in the herds.

\section{Competing interests}

The authors declare that they have no competing interests.

\section{Availability of data and materials}

The datasets used and/or analysed during the current study are available from the corresponding author on reasonable request.

\section{Consent for publication \\ Not applicable.}

\section{Ethics approval and consent to participate}

This study did not require official or institutional ethical approval. The animals were handled according to high ethical standards and national legislation.

\section{Funding}

Pharmacosmos A/S, Denmark funded the hematologic testing and transport. The funding body had no role in the study design, collection of samples, analyses, interpretation or preparing of the manuscript.

\section{Prior publication}

Data have not been published previously.

\section{Publisher's Note}

Springer Nature remains neutral with regard to jurisdictional claims in published maps and institutional affiliations.

Received: 3 January 2019 Accepted: 22 March 2019

Published online: 27 March 2019 


\section{References}

1. Thorn CE. Hematology of the pig. In: Weiss DJ, Wardrop KJ, editors. Schalm's veterinary hematology. lowa: Wiley-Blackwell; 2010. p. 848

2. Elbers AR, Geudeke MJ, Van Rossem H, Kroon MC, Counotte CH. Haematology and biochemistry reference values for sows kept under modern management conditions. Vet Q. 1994;16:127-30. https://doi. org/10.1080/01652176.1994.9694433.

3. Friendship RM, Lumsden J, McMillan I, Wilson M. Hematology and biochemistry reference values for Ontario swine. Can J Comp Med. 1984;48:390.

4. Bhattarai S, Nielsen JP. Early indicators of iron deficiency in large piglets at weaning. J Swine Health Prod. 2015;23:10-7.

5. Tybirk P, Sloth NM, Kjeldsen N, Shooter L. Danish nutrient standards. 2018. http://pigresearchcentre.dk/ /media/Files/PDF\%20-\%20UK/Normer/ Normerseptember2018UKLISHudgave_28.pdf. Accessed 27 Feb 2019.

6. Egeli A, Framstad T, Grønningen D. The effect of peroral administration of amino acid-chelated iron to pregnant sows in preventing sow and piglet anaemia. Acta Vet Scand. 1998;39:77-87.

7. Perri AM, O'Sullivan TL, Harding JC, Wood RD, Friendship RM. Hematology and biochemistry reference intervals for Ontario commercial nursing pigs close to the time of weaning. Can Vet J. 2017;58:371.

8. Warren KS, Holyoake CS, Friend TJ, Yeap L, McConnell M. Hematologic and serum biochemical reference intervals for the bilby (Macrotis lagotis). Wildl Dis. 2015;51:889-95. https://doi.org/10.7589/2014-03-074.

9. ASVCP. Quality Assurance and Laboratory Standards Committee (QALS) Guidelines for the Determination of Reference Intervals in Veterinary Species and other related topics: SCOPE. American Society for Veterinary Clinical Pathology (ASVCP). [18 October 2010]. https://www.asvcp.org/ pubs/pdf/RI\%20Guidelines\%20For\%20ASVCP\%20website.pdf. Accessed 20 July 2017.
10. Geffré A Concordet D, Braun JP Trumel C Reference value advisor: a new freeware set of macroinstructions to calculate reference intervals with Microsoft Excel. Vet Clin Pathol. 2011;40:107-12. https://doi.org/10.1111/ j.1939-165X.2011.00287.x.

11. Humann-Ziehank E, Ganter M. Pre-analytical factors affecting the results of laboratory blood analyses in farm animal veterinary diagnostics. Animal. 2012;6:1115-23. https://doi.org/10.1017/S1751731111002679.

12. Roscoe M, Donaldson G. The blood in pregnancy; Part II. The blood volume, cell volume and haemoglobin mass. Obstet Gynecol Surv. 1947;2:291-3. https://doi.org/10.1111/j.1471-0528.1946.tb05781.x.

13. Breyman C, Huch R. The physiology of haemopoiesis in pregnant women Anaemia in pregnancy and the puerperium. Bermen: International Medical Publishers; 2011. p. 28-31.

14. Roepstorff A, Nilsson O, O'Callaghan C, Oksanen A, Gjerde B, Richter $S$, et al. Intestinal parasites in swine in the Nordic countries: multilevel modelling of Ascaris suum infections in relation to production factors. Parasitology. 1999;119:521-34.

15. Hansen C. National average productivity in pig production in 2017 (Landsgennemsnit for productivitet i svineproduktionen 2017). https:// svineproduktion.dk/publikationer/kilder/notater/2018/1819. Accessed 03 Jan 2019.

16. Xiao Y, Yu S, Xu Y. The prevalence and biochemical profiles of EDTAdependent pseudothrombocytopenia in a generally healthy population. Acta Haematol. 2015;134:177-80. https://doi.org/10.1159/000373915.

17. Arghirescu S, Bătăneant $M$, Jinca C, Pascalău $A$, Lelik M, Preja M, et al. Multi-anticoagulant and EDTA dependent pseudothrombocytopenia. Case reports on two pediatric patients. Rev Rom Med Lab. 2014:22:191-8. https://doi.org/10.2478/rrlm-2014-0017.
Ready to submit your research? Choose BMC and benefit from:

- fast, convenient online submission

- thorough peer review by experienced researchers in your field

- rapid publication on acceptance

- support for research data, including large and complex data types

- gold Open Access which fosters wider collaboration and increased citations

- maximum visibility for your research: over $100 \mathrm{M}$ website views per year

At $\mathrm{BMC}$, research is always in progress.

Learn more biomedcentral.com/submissions 